\section{SCIENCE IN ITALY'}

I $\mathrm{N}$ reviewing a number of scientific pamphlets, \&c., from Italy, we took occasion to remark (NATURE, vol. xiii., p. I10) that "the restoration of political unity and freedom in Italy has also brought about a revival of that intellectual vigour which we are accustomed to associate with the names of Dante and Tasso, of Galileo and Torricelli. When Italy was divided and each state politically oppressed, her best men were in exile, and their best scientific work was expressed in a foreign tongue."

In forwarding to us a copy of the handsome volume, the title of which is given above, the editors have written to us, quoting the foregoing passage with approval, while the introduction to the volume is written in the spirit of those remarks. It is gratifying to learn what progress Italy has made during the last ten or fifreen years in education, literature, science, commerce, and industry. "An air more propitious to study is now breathed by united Italy." New scientific schools, institutions, and societies have sprung up, and the old have been renovated. The best men, returned from exile, have resumed their place among the explorers of nature; and the present state of intellectual activity only renders more evident the condition of misrule and division which so long afflicted that noble country, when all free inquiry, whether in nature or in politics, was forbidden, or at least discouraged. In singular contrast to all this, her best minds have at length found that intellectual repose and encouragement at home which are so essential to the carrying on of grave studies.

As an exponent of this new state of things, the editors conceived the idea of publishing a half-yearly report of the scientific progress of Italy; and taking advantage of that wide spirit of tolerant liberality which pervades all true science, they appealed for support to such of their countrymen as were distinguished in the various departments of physics, chemistry, mineralogy, geology, botany, zoology, physiology, anthropology, and geography. This appeal was most liberally and heartily responded to, and the result is a large octavo volume of about 450 pages, well written and carefully edited, very few mistakes occurring, even in the spelling of well-known names, although we find at p. 15, "Poulliet,"at p. 68, "Bences Jones," at p. 84, "Edvard Hull," and this odd mode of division at p. I5, "Hel-mholtz." The contributors to these various departments have performed their respective tasks nobly and well. 'They have not only contributed voluminous abstracts of papers, notes and memoirs, but in many cases have furnished more or less elaborate reports on the state of their respective branches of science, and have also given, in some cases, reviews of the best books by Italian authors. For example, the reporter on mineralogy, in addition to some sensible remarks on the backward state of science in Italy, devotes thirty full pages to a review of Bambicci's "Corso di Mineralogia" (second edition, I 875), and refers to it again and again in terms of such high praise as would seem scarcely to belong to a compilation from standard writers in other languages. Indeed the superlative terms of laudation which occur in many parts of the volume strike our colder northern temperament as being at least exaggerated. Why refer to the chiarissimo Signor Professore, So-and-So, while foreign savans, whether living or departed, are simply and properly mentioned, as Ampère, Faraday, Helmholtz, \&c. When Lord Castlereagh appeared in plain evening dress at a brilliant party at Vienna, amidst a crowd of highlydecorated gentlemen, a lady, asking Metternich who he was, said, "Mais il n'est pas distingué !" that statesman replied, "Ma foi! c'est être bien distingue."

Although we are bound to bestow cordial praise on this volume, yet we should not perform our duty

× Half-yearly Review of the Physico-Natural Sciences in Italy. Edited and published by Drs. G. Cavanna and G. Papasogli. Anno I., 1875, vol. i. Florence, 3875 , (Rassegna Semestrale, \&c.) honestly if we omitted to point out a certain backwardness on the part of some investigators in reacting up their subjects before they attempted to make what to them appear to be new researches. For example, at p. 66 is an abstract of a memoir by Pelloggio, entitled "Contribution to the Phenomena of Supersaturation," in which the author appears to have no more recent information of his subject than that derived from Löwel. He points out that salts isomeric with the one in solution act as nuclei to it. This was shown to be the case many years ago by Violette. He also insists that porous bodies, such as sponge, charcoal, \&c., are powerful nuclei; whereas it has been shown by Tomlinson that such bodies, boiled with the solution which is then left to cool, are purely passive. So also when MM. Mercadante and Colosi affirm (p, 47) that carbonic acid is not emitted by the roots of plants, they are evidently unacquainted with Broughton's researches. We may also point out what seems to be an inaccurate observation on the part of Pollacci (p. 5o), namely, that sulphur moistened and exposed to the air absorbs oxygen and becomes converted into sulphuric acid.

At p. 126 there is an interesting account of the fall of a meteor at Supino in the district of Frosinone on Sept. 14, 1875. It was accompanied by a trail of fire and smoke; and after reaching the earth it took a horizontal direction, passed through a house without striking it, thanks to an open passage, and so disappeared. A number of fragments were found in the passage, the heaviest of which weighed 364.2 grammes. The fragments were warm. At p. I 34 is a paper on red chalk, which would deserve attention did our space permit.

Anthropology and ethnology are comparatively new to Italy, but they have begun a life of apparent vigour under the auspices of a new society, a museum, and a journal.

There are some interesting details respecting the skulls of Dante, Petrarch, Ugo Foscolo, and Volta, the last being of extraordinary capacity. In the skull of Petrarch the Etruscan type is said to be evident, namely, a voluminous brain, strongly developed in all its parts, and of superior psychological power; but the posterior predominates over the anterior portion, leading to the conclusion that the sentiments and the instincts prevailed over the intellect, although this is of the highest order.

We look out with much interest for the second part of this volume, which the editors promise shall appear shortly.

C. TOMLINSON

\section{THE VOLCANO OF REUNION ${ }^{1}$}

$T H E$ volcano of the Island of Réunion, surrounded and defended as it were by great circular walls perpendicular for more than roo metres, forming what is known as the inclosure, is hardly accessible except on two sides, by the high plain of the interior or by the Grand-Brule; that is, setting out from the coast to climb directly the slopes of the crater itself.

Far from becoming extinct, as has been supposed, this volcano is on the contrary in great activity, and almost every year torrents of lava overflow in that western part of the island known as the great burnt country; its streams sometimes reach the sea, and there form, at a height of more than 2,000 metres, a regular cascade of fire, which may reach a length, as in 1844 , of from 900 to I,, 00 metres. But these great eruptions are happily very rare; they are only seen at intervals of six or eight years, and very often the lava is arrested 1,000 or $\mathrm{J}, 500$ metres from the mouth of the crater. Towards the end of August, I874, loud detonations, sudden tremblings of the ground presaged an eruption of great violence ; but the flow lasted only two days; directed towards the rampart of the Tremblet, it was happily arrested at I,500 metres without causing much damage. It was then that I arrived

I From an article in La Nature, No. 160, by M. Ch. Vellain. 
in the harbour of St. Denis ; and on landing I organised, with MM. Rochefort, Cazin, and De l'Isle an expedition to the volcano in the hope of arriving in time enough to witness the end of the eruption. We set out from St. Benoit on Sept. I, and made for the plain of Palmistes, our first stage. This plain is surrounded on all sides, except the north-east, by perpendicular ramparts, which may reach a height of 200 metres, and whose sides, covered with vegetation, form a semicircular curtain of verdure that shuts out the horizon.

From the plain of the Palmistes we had to climb to that of Cafres by crossing the rampart of the Grande-Montée, a long and difficult ascent on account of the abruptness of the rampart. We reached the summit about an hour after mid-day, and found the temperature to be $14^{\circ} \mathrm{C}$., less than half that of the lower part of the island. The plain of Cafres, at a mean height of 1,600 metres, forms a declivity, a sort of saddle-back or pass between the two parts of the island which we have distinguished under the names of Ancient Mass and Recent Mass. It is a very uneven plain, inclined towards the south-west, i.e., in a direction opposite to that of the Palmistes, and formed by a succession of small echeloned plateaus crossed by rounded hillocks covered with vegetation. The soil which results from the disintegration of the lavas is here very argillaceous, as all that savannah presents fresh pasturage during the dry season, and is changed into a vast marsh during the rainy season; it is about two leagues in length. Night surprised us near the source of the river of the Ramparts before we could reach the end of our journey, and we had to sleep on the bare ground; the thermometer reached $3^{\circ}$, and during the night sank to $-2^{\circ}$.

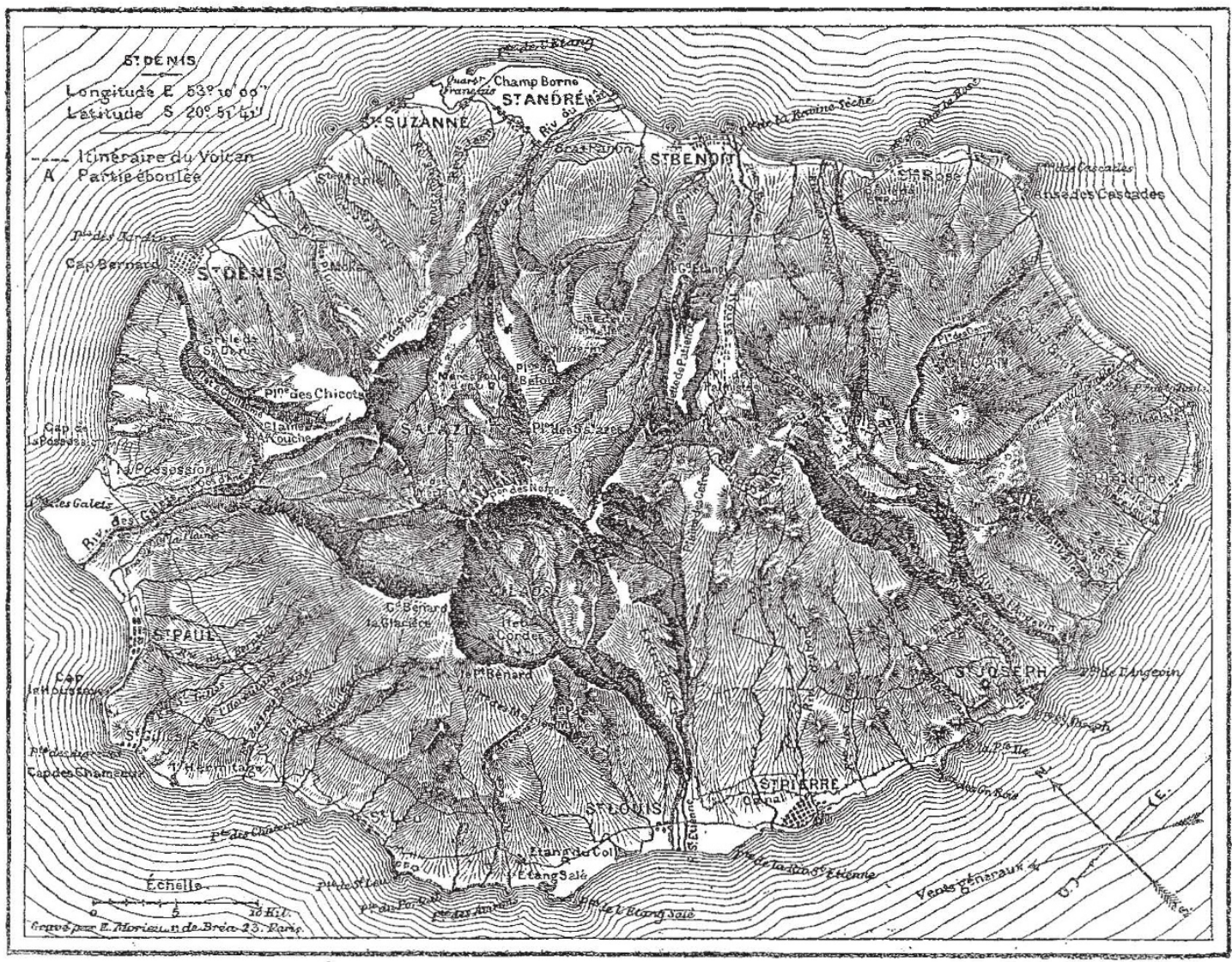

Map of the Island of Réunion (after M. L. Maillard).

At eleven on the next morning we reached the Cavern of the Lataniers, after having visited the vast crater named Commerson, singularly situated on the very edge of the magnificent escarpments which form the great section at the foot of which flows the river of the Ramparts; from thence we directed our steps towards the pass of the sands ( 2,386 metres), in order to cross the first inclosure of the volcano. The present volcanic cone is, in fact, preceded by two great circles produced by subsidences which have given place to veritable circular walls cut perpendicularly for more than Ioo metres from the top, and which are named the inclosures. Of the first there remains only a small part; on the north-east its wall overhangs the river from the tast, and on the east the plain of sands; but on the south it is not so easily traced; it is prolonged on this side of the great section of the river Angevin, the formation of which is later.

The plain of sands (about 2,300 metres) which thus circumscribes a basaltic rampart, is formed by a black compact lava covered by a layer of small angular very regular fragments of vitreous lava, often two metres in thickness. In the bottom of the little ravines is noticed, moreover, an accumulation of crystals of olivine and augite which come from the disintegration of certain rocks thrown out by the volcano, and composed almost solely of these two minerals. It is intersected by cones of scoriæ regular in form, terminating in little craters, the limited overflows from which appeared consolidated on the ledge. We had to pass round many of them before arriving at the ridge of the second inclosure, which had 
to be crossed at the Belcombe pass $(2,400 \mathrm{~m}$.). The of Bois Blanc and the Rampart of Tremblet, and which diameter of the latter is about 5,000 metres ; it is disposed surround the great burnt region; here is the mass of the in horsehoe form, and is prolonged eastwards by two great present volcano.

parallel walls, which are named respectively the Rampart $\mid$ When we reached the top of the rampart the descent

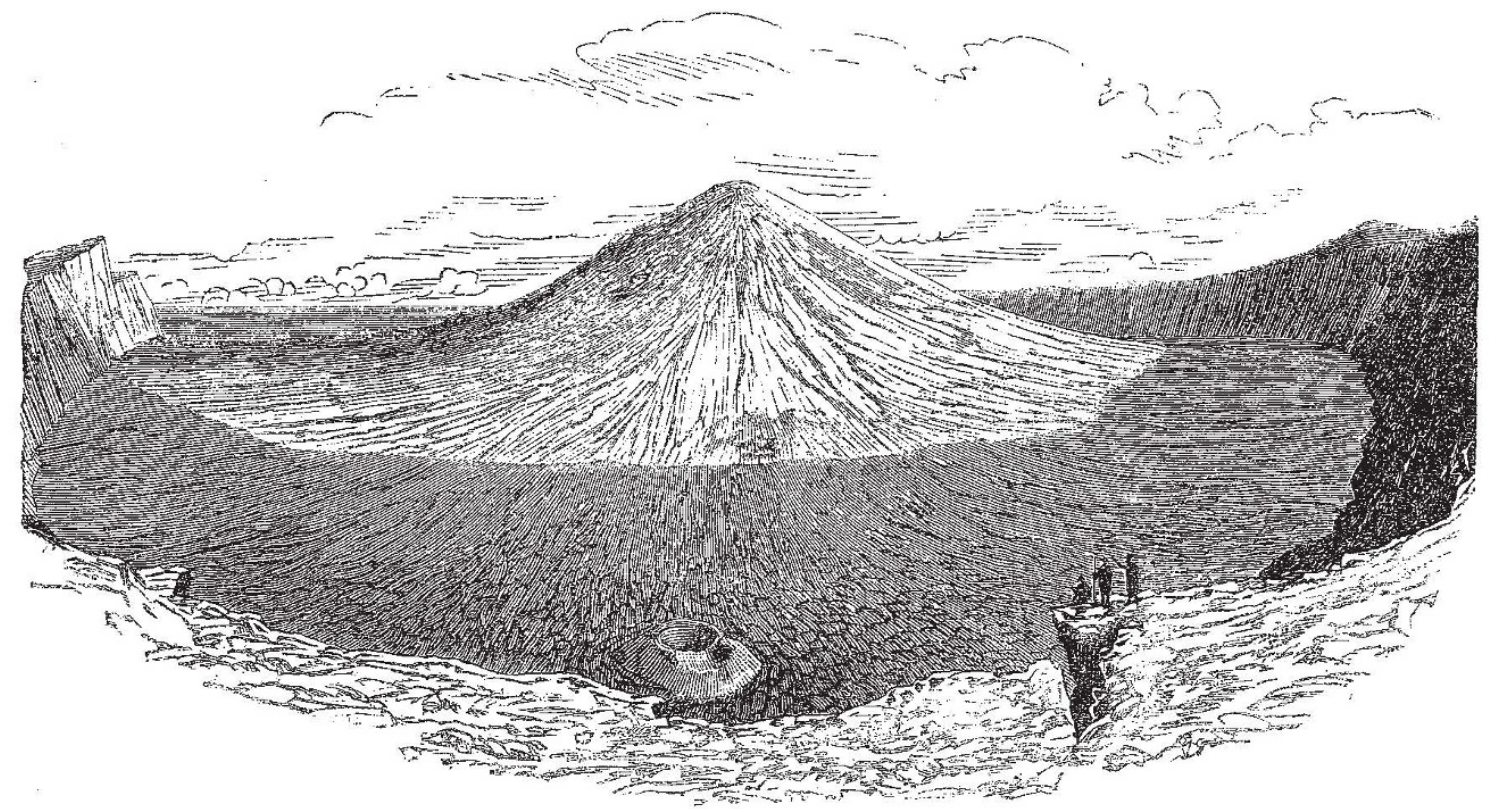

The Formica.leo and the Bory Peak (extinct crater) froin above the Pass of Belcombe.

looked dreadful, and appeared perpendicular to a depth / volcanic mountain, whose slopes they cover to an equal of 250 metres. Below, sombre-coloured lavas stretched height all round; there is detachea trom the foot of the out in a sort of platform which serves as a base to the rampart a little cone of scoriæ in admirable preservation,

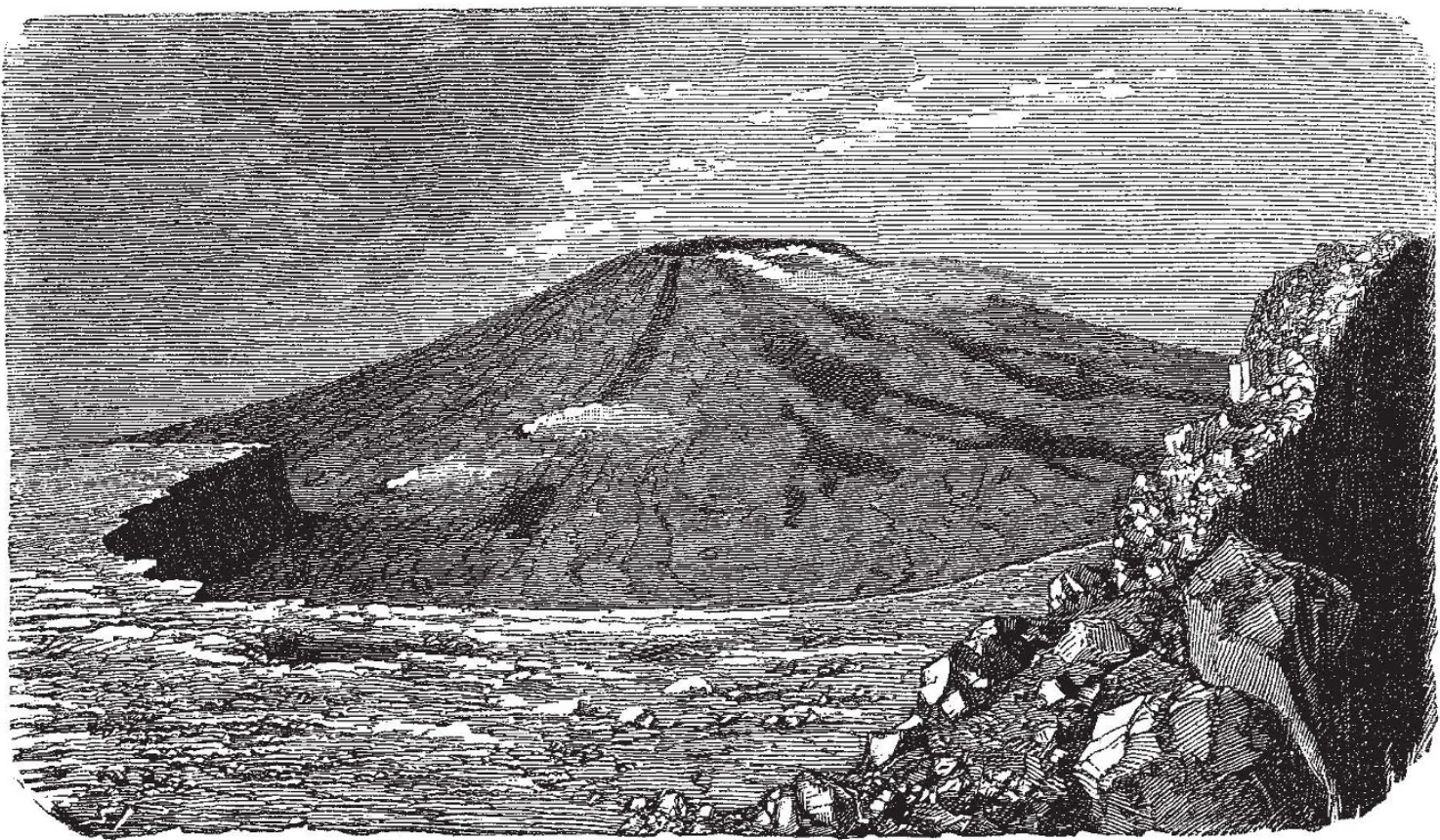

The Inclosure and the Cone of the present Crater.

which Bory de St. Vincent has named the Formica-leo (Ant-lion). Attempting the descent by the help of some shrubs which had lodged themselves in the interstices of the wall, we reached with difficulty the base of the escarpment. The Formica-leo, which, seen from above, appeared quite near, was more than 300 metres from us, 
It is a very flattened cone, perfectly regular, I 5 metres high on a base of from 1,000 to 1,200 metres, presenting at the summit an opening of about 80 metres, with a depth of 6 metres. It is formed entirely of brightcoloured scoriæ, black, yellow, but mostly red.

On the morrow, after having passed the night under a break in the lava of the rampart, exposed to the moisture and to a glacial wind, we ascended the slopes of the Bory Peak, in order to reach the burning crater. On our arrival at the mouth of the crater all the volcanic phenomena had ceased; on the slopes of the cone, formed of scoriæ and heaps of ashes is detached a black stream of vitreous lava which made its way by numerous fissures to about roo melres from the summit. The cooled lava formed at the bottom of the crater a circular shaft about 80 metres in depth, like a solid crust much fissured. Abundant vapours escaped from various points in the walls, which presented alternate streams of lava and scoriæ, covered, especially towards the summit, by a whitish coating, formed of the crystals of gypsum. The lava of the last eruption had flowed to the north-east towards the plain of Osmondes; it was not very extensive, very scoriaceous, bluish-black, and entirely vitreous. it must have been accompanied or followed by numerous ejections and perticularly by a rain of those volcanic threads so frequently thrown out by the volcanoes of the Sandwich Islands, and known as Pele's Hair; for these brown filaments, which are simply wiredrawn obsidians, bedecked all the irregularities of the lava. In the crevasses which crossed the last flow, the temperature was $50^{\circ} \cdot 7$ near the surface, and about $72^{\circ}$ at 2 metres below. The vapours of water and of hydrochloric acid were given off at frequent intervals here as well as at various points of the escarpment which directly preceded the volcanic cone. A small inclosure, not hitherto referred to, surrounded the crater; its precipices were about 60 metres high. The mass of the volcano is thus composed of two peaks, the highest of which $(2,625$ metres) supports the crater Bory, extinct since the begiming of the century; while the other (the Fournaise peak, 2,5 ' 5 metres), which is of later formation, supports the active crater. The products of this volcano are composed mainly of basaltic or vitreous lavas rich in chrysolite ; this mineral, so characteristic of modern eruptions, is often ejected in voluminous and compact masses. The products of the old volcano, which must at one time have occupied the centre of the three valleys of Cilaos, Salazie, and Mafatte, are quite different; they are scattered over a trachytic mass which is only seen, however, in the beds of the torrents which drain the three circles above referred to.

Our porters, whom the sight of the volcano deeply impressed, were unwilling to follow us on to the lavas; they remained at the Belcombe Pass, and would not on any account on our return take charge of the rocks and volcano products which I had collected. Some maintained that stones were plentiful enough on the shore, and that it was useless to carry them from such a height; others, affecting a gross superstition, would not touch what came from the "fire of the good God." I had to use a little trickery, and take advantage of the darkness to slip into their sacks my day's collection.

\section{ARCTIC FOSSIL FLORA'}

THIS third volume of Dr. Heer's "Fossil Flora of the Arctic Regions" contains four very distinct chapters. The first of these relates to the Plants of the Coal-measures of the Arctic Zone ; the second to the Plants of the Chalk Formation of the same Zone; the third gives an

I "Flora Fossilis Arctica." Die Fossile Flora der Polarländer von Dr. Oswald Heer. Dritter Band. (Zurich, 1875.) account of the Miocene Flora of Greenland; and the fourth is a review of the Miocene Flora of the Arctic Zone. For the material for the first three chapters of this volume the author has the Swedish naturalists alone to thank, and in addition, the Swedish Academy of Sciences has been at the expense of the several parts composing it, which will also be found in Vols. 12 and 13 of their "Abhandlungen." The fourth chapter is added at the expense of Dr. Heer, and not only notices the Miocene plants referred to in the three first volumes, but also those collected during the summer of 1873 in Spitzbergen by Prof. Nordenskjöld.

It would not be desirable here to do more than notice the general contents of this quarto volume, which contains notices of four species of plants found in the lower coalmeasures of Spitzbergen; of seventy-five species from the lower and of sixty-five species from the upper chalk of Greenland, of sixteen species from the chalk of Spitzbergen, and of thirty-four species from the Miocene of Greenland, most of these species are illustrated in the forty-nine plates which accompany the volume. One remarkable fern, Protopteris punctata, Stbg., is referred to in the text as a proof of the occurrence of the coalmeasures at Ujarasusuk at Disco. It was originally described from specimens found in the sandstone of Kaunitz, in Bohemia, which had been most generally described as belonging to the coal-measures; it would seem, however, from the researches of Herr Feistmantel that the Kaunitz sandstone really belongs to the chalk formation, thus doing away with the only point which for a moment seemed to favour the existence of the coal formation in Greenland, seeming to prove that on both sides of the Waigat, at Disco, and at Half Island, Noursoak, the oldest sedimentary formations are chalk deposits. These from the former locality apparently belong to the Upper Cretaceous period, while the dark-brown rocks and sandstones of the north side of the latter locality belong to the Lower Cretaceous period. Higher up succeed the Miocene deposits, which are covered and penetrated by intrusions of the mighty basalt rock.

From the many various localities now known in the Arctic regions for fossil plants, none indicating a marine origin have occurred to Dr. Heer. Steenstrup, jun., however, has detected the remains of some marine animals from the district of Atane, between Patut and Niick Kiterdlek; here, in several places at an elevation of some 2,000 feet over sea-level, he found Echinoderms and marine shells. Cyclostigma Nathorsti, very near C. Kiltorkense, Haughton, is described as new from the coal of Spitzbergen.

A glance at the list of the Miocene plants shows how changed the seasons in the Arctic Zone must be from the time when these plants were living and bearing the leaves which have been so well preserved. Hawthorn and brambles, walnuts, magnolias, and vines, not to allude to planes, Macclintockias, and many of the more delicate Conifers, seemed to have flourished ere the reign of ice came and burnt them up. The list of cretaceous fossil plants from North Greenland is accompanied by a list of the localities where they were collected. The collection, a very large one, is for the most part in the museum at Stockholm; many of the species are described as new. The absence of insect life amid all this plant life is noteworthy, but two species, probably weevils, being described in this volume.

Many countries have contributed the material for Prof. Heer to work out the history of the "Flora of the Arctic World." A great deal still remains to be done. Now that England, Denmark, and Sweden have done so much, we must look to Russia to contribute according to her means and the extent of her Arctic possessions; she has done nobly in tracing out the contour line of her northern coast. We would now know more of the rocks that form it.

E. P. W. 